\title{
Placenta-derived multipotent cells have no effect on the size and number of DMH-induced colon tumors in rats
}

\author{
HANNA SVITINA $^{1,2}$, VITALIY KYRYK ${ }^{3}$, INESSA SKRYPKINA ${ }^{1,4}$, MARIA KUCHMA $^{1,4}$, TETIANA BUKREIEVA ${ }^{1}$, \\ PAVLO ARESHKOV ${ }^{1,4}$, YULIA SHABLII ${ }^{1}$, YEVHENIY DENIS ${ }^{2}$, PAVLO KLYMENKO ${ }^{3}$, \\ LIUDMYLA GARMANCHUK ${ }^{2}$, LIUDMYLA OSTAPCHENKO ${ }^{2}$, \\ GALINA LOBINTSEVA $^{1}$ and VOLODYMYR SHABLII ${ }^{1,2}$

\begin{abstract}
${ }^{1}$ Cell Culture Laboratory, Cryobank, Institute of Cell Therapy, 03680 Kyiv; ${ }^{2}$ Department of Biochemistry, Educational and Scientific Centre "Institute of Biology and Medicine", Taras Shevchenko National University of Kyiv, 01601 Kyiv;

${ }^{3}$ Department of Cell and Tissue Technologies, State Institute of Genetics and Regenerative Medicine of Academy of Medicine of Ukraine, 04114 Kyiv; ${ }^{4}$ Department of Functional Genomics, Institute of Molecular Biology
\end{abstract} \\ and Genetics of National Academy of Science of Ukraine, 03680 Kyiv, Ukraine
}

Received July 26, 2016; Accepted April 21, 2017

DOI: $10.3892 /$ etm.2017.4792

\begin{abstract}
Transplantation of placenta-derived multipotent cells (PDMCs) is a promising approach for cell therapy to treat inflammation-associated colon diseases. However, the effect of PDMCs on colon cancer cells remains unknown. The aim of the present study was to characterize PDMCs obtained from human (hPDMCs) and rat (rPDMCs) placentas and to evaluate their impact on colon cancer progression in rats. PDMCs were obtained from human and rat placentas by tissue explant culturing. Stemness- and trophoblast-related gene expression was studied using reverse transcription-polymerase chain reaction (RT-PCR), and surface markers and intracellular proteins were detected using flow cytometry and immunofluorescence,
\end{abstract}

Correspondence to: Dr Hanna Svitina or Dr Volodymyr Shablii, Cell Culture Laboratory, Cryobank, Institute of Cell Therapy, 3 Kosmonavta Komarova Avenue, 03680 Kyiv, Ukraine

E-mail: anja.onishchenko@gmail.com

E-mail:v_shabliy@ukr.net; v.shabliy@stemcellclinic.com.ua

Abbreviations: MSCs, mesenchymal stem cells; BM-MSCs, bone marrow-derived MSCs; PDMCs, placenta-derived multipotent cells; SCID, severe combined immunodeficiency; DMH, dimethylhydrazine; DMEM, Dulbecco's modified Eagle's medium; FBS, fetal bovine serum; rPDMCs, rat PDMCs; hPDMCs, human PDMCs; CD, cluster of differentiation; PBS, phosphate-buffered saline; BSA, bovine serum albumin; GAPDH, glyceraldehyde 3-phosphate dehydrogenase; ACTB, $\beta$-actin; FISH, fluorescence in situ hybridization; EOMES, eomesodermin; CDX2, caudal type homeobox 2; ID2, inhibitor of DNA binding 2; POU5F1, POU class 5 homeobox 1; Prl3b1, prolactin family 3 , subfamily b, member 1 ; Tpbpa, trophoblast specific protein $\alpha$; CGB, choriogonadotropin subunit- $\beta$

Key words: PDMCs, MSCs, colon cancer, DMH respectively. Experimental colon carcinogenesis was induced in male albino Wistar rats by injecting $20 \mathrm{mg} / \mathrm{kg}$ dimethylhydrazine $(\mathrm{DMH})$ once a week for 20 consecutive weeks. The administration of rPDMCs and hPDMC was performed at week 22 after the initial DMH-injection. All animals were sacrificed through carbon dioxide asphyxiation at week 5 after cell transplantation. The number and size of each tumor lesion was calculated. The type of tumor was determined by standard histological methods. Cell engraftment was determined by PCR and immunofluorescence. Results demonstrated that rPDMCs possessed the immunophenotype and differentiation potential inherent in MSCs; however, hPDMCs exhibited a lower expression of cluster of differentiation 44 and did not express trophoblast-associated genes. The data of the present study indicated that PDMCs may engraft in different tissues but do not significantly affect DMH-induced tumor growth during short-term observations.

\section{Introduction}

Transplantation of mesenchymal stem cells (MSCs) is a promising method of treating inflammatory bowel diseases (1-4). However, to the best of our knowledge, the effect of this approach on colon tumor initiation and progression remains unknown. Colorectal cancer remains the second most commonly diagnosed cancer in Europe and the third in the USA $(5,6)$. As a large proportion of individuals fail to get checked, only $39 \%$ are diagnosed at an early stage when the 5 -year survival rate is $90 \%$ (6). When colorectal cancer is diagnosed at later stages, the prognosis is poor and the 5-year survival rate reduces to $11-69 \%(5,6)$. Due to government support for early colon cancer screening programs in the majority of countries, the identification of novel therapeutics to treat tumors following diagnosis during the middle and late stages is required (7).

The effects of MSCs on cancer development have been studied using in vitro co-culture (8) and xenograft models 
where human cells were transplanted into rodents $(9,10)$. In addition, in vivo antitumorigenic activities of stem cells have largely been evaluated based on changes in the growth and weight of xenograft tumors in immune-deficient hosts (11-16), which differ from humans or animals with spontaneous cancer. The allogeneic models where donor and recipient are the same species have a lot of advantages in the study of therapeutic potential of administered cells on tumor progression compared with xenogeneic models $(17,18)$. Allogeneic models allow the influence of stem cell administration on the immune system to be evaluated (19) and this may change the outcome of treatment, despite evidence indicating that MSCs are able to escape recognition by using alloreactive $\mathrm{T}$ cells and natural killer cells (20).

The therapeutic effect of bone marrow-derived MSCs (BM-MSCs) on cancer development is controversial. According to previous studies, the antitumor effect of BM-MSCs was only detected during the early stages of colon carcinogenesis (21-23). BM-MSCs do not have an effect on tumor growth when administered in the later phases of colon carcinogenesis (21). However, in syngeneic immunocompetent mice, it was demonstrated that increased tumor growth or elimination of tumor formation depended on the proportion of injected murine MSCs and Renca tumor cells (24). Additionally, research has demonstrated an acceleration of tumor progression following the co-injection of MSCs with cancer cells as MSCs are involved in the formation of the vascularized environment $(21,22)$. Placenta-derived multipotent cells (PDMCs) are widely used as an allogeneic cell therapy product to treat Crohn's disease (1) and ulcerative colitis (25), both of which often present with complications, such as colon carcinogenesis. There is evidence of antitumor effects of placenta-derived substances and mesenchymal stem cells (26-30). Human placenta-derived adherent cells have the capacity to translocate and survive in rabbit myelomatous bone transplanted into severe combined immunodeficient (SCID) mice (27). In addition, human placental MSCs contain therapeutic genes for the treatment of ovarian cancer (28) and melanoma (29). Human placenta was reported to secrete agents that induce apoptosis and reduce cancer cell proliferation of non-small cell lung cancer tissue and A549 cell line culture (26) and breast cancer cell lines, MCF7/T47D (31). A study by Pavlidis and Pentheroudakis (32) suggested that, typically, metastases did not spread to the fetus during pregnancy due to the protective role of the placenta.

It is important to establish the ontology of PDMCs, since the development of rodent and human placenta differs. For example, rat placenta contains three distinct cell types, including extraembryonic mesoderm, trophoblast and extraembryonic endoderm localized in the sinus of Duval (33). By contrast, the human placenta does not contain endodermal cells as the yolk sac is not involved in placental development (34).

In the present study, a dimethylhydrazine (DMH)-induced colorectal carcinogenesis model was used to assess the effect of the intravenous transplantation of PDMCs on tumor growth and progression. DMH specifically induces tumors within the descending colon, with histopathology similar to that of human sporadic colon tumors $(35,36)$. The primary aim of the present study was to characterize placenta-derived stem cells and to determine the effect of intravenous transplantation of
PDMCs on tumor growth in mid/late-stage DMH-induced colorectal carcinogenesis in rats.

\section{Materials and methods}

Isolation and culture of human and rat PDMCs. A total of 3 rats were obtained from Central Animal House of the Education and Scientific Centre Institute of Biology and Medicine of Taras Shevchenko National University of Kyiv (Kyiv, Ukraine). The animals were maintained under 12-h light/dark cycle, $60 \%$ humidity at $20-22^{\circ} \mathrm{C}$ and fed on standard diet and tap water ad libitum. A total of 3 female rats (weighing 350-450 g, 11-14 months old) were sacrificed on day 21 of pregnancy through carbon dioxide asphyxia. Briefly, the $\mathrm{CO}_{2}$ flow rate was started with $8 \mathrm{l} / \mathrm{min}$ in a 30 -liter chamber. As unconsciousness will occur as indicated by a loss of the righting reflex, the flow of the gas was increased to $12 \mathrm{l} / \mathrm{min}$ to fill the chamber and decrease the time to death. $\mathrm{CO}_{2}$ flow was maintained for at least $1 \mathrm{~min}$ after respiratory arrest. Death was confirmed when the animal was unresponsive to a toe pinch. From 3 pregnant rats, a total of 24 fetuses with placentas (10 male fetuses and 14 female fetuses) were obtained and the placentas from male fetuses were immediately collected and processed. To verify the cell origin by fluorescent in situ hybridization (FISH), the rat placentas from male fetuses were selected $(n=10)$.

A total of 4 human male $(n=3)$ and female $(n=1)$ term placentas (vaginal delivery or Caesarean section) were obtained in May 2013 at Kyiv City Maternity Hospital No. 3 (Kyiv, Ukraine) from 23-36-year old donors at 39-41 weeks of gestation. Written informed consent was obtained from all participants. The current study and the consent procedures were approved by the Institute of Cell Therapy Committee on Human Research (\#2-13; Kyiv, Ukraine). All animal experiments were performed in accordance with the international principles of the European Convention for the Protection of Vertebrate Animals used for Experimental and Other Scientific Purposes (European Convention, Strasburg, 1986) and Article 26 of the Law of Ukraine 'On protection of animals from cruelty’ (no. 3447-IV, 21.02.2006), in addition to following all norms of bioethics and biosafety. The protocol was approved by The Bioethics Committee of The Education and Scientific Centre 'Institute of Biology and Medicine' of Taras Shevchenko National University of Kyiv (protocol no. 8, 03.04.14; Kyiv, Ukraine).

The placentas were washed three times for $2 \mathrm{~min}$ in Hank's balanced salt solution (Hyclone; GE Healthcare Life Sciences, Logan, UT, USA) supplemented with penicillin and streptomycin (100 U/ml and $50 \mathrm{mg} / \mathrm{ml}$, respectively; Arterium Corp., Kyiv, Ukraine). The villous tissues were dissected into sections, $\sim 1-5 \mathrm{~mm}^{3}$, using surgical scissors and forceps. Human and rat placental fragments were washed intensively for $1 \mathrm{~h}$ on a shaker in Hanks' balanced salt solution supplemented with penicillin $(100 \mathrm{U} / \mathrm{ml})$ and streptomycin $(50 \mathrm{mg} / \mathrm{ml})$ until the washing solution became colorless. The tissue fragments were then placed in cell culture dishes (Sarstedt AG and Co., Nümbrecht, Germany). To allow cell migration from the tissue onto the culture plate, human tissue fragments were covered with high-glucose Dulbecco's modified Eagle medium (DMEM; Hyclone; GE Healthcare Life Sciences) 
supplemented with $10 \%$ fetal bovine serum (FBS; Hyclone; GE Healthcare Life Sciences), and rat tissue was covered with high-glucose DMEM supplemented with 7\% FBS and 3\% rat serum (BioWest, Nuaillé, France). Primary cultures were cultivated in standard conditions, as follows: a $90 \%$ humidified atmosphere, at $37^{\circ} \mathrm{C}$ with $5 \% \mathrm{CO}_{2}$, and the culture medium was changed twice a week. Cells were passaged via $0.05 \%$ trypsin dissociation (Biochrom AG, Berlin, Germany). When the colonies reached a confluence of $90 \%$ they were seeded at a density of $5 \times 10^{3}$ cells $/ \mathrm{cm}^{2}$.

Osteogenic differentiation assay. To assess the osteogenic capacity, rat PDMCs (rPDMCs) were treated with osteogenic differentiation medium containing $0.1 \mathrm{mM}$ ascorbic acid 2-phosphate, $10^{-7} \mathrm{M}$ dexamethasone, $10 \mathrm{mM}$ $\beta$-glycerophosphate (all from Sigma-Aldrich; Merck KGaA, Darmstadt, Germany) and 10\% FBS in high-glucose DMEM. rPDMCs were seeded at $5 \times 10^{3}$ cells $/ \mathrm{cm}^{2}$ into Nunc ${ }^{\mathrm{TM}}$ 4-well dishes (Sigma-Aldrich; Merck KGaA) at passage 3. When the cells reached $80-90 \%$ confluence, the cell growth medium (as described above) was changed to osteogenic differentiation medium, and the cells were incubated in standard conditions (a $90 \%$ humidified atmosphere at $37^{\circ} \mathrm{C}$ with $5 \% \mathrm{CO}_{2}$ ) for 21 days. The differentiation medium was changed twice a week. Following differentiation, the cells were stained with Alizarin Red S (Sigma-Aldrich; Merck KGaA), to detect calcium deposition. For Alizarin Red S staining, the cells were washed three times with phosphate-buffered saline (PBS) and fixed with ice-cold $70 \%$ ethanol for $5 \mathrm{~min}$ at $4^{\circ} \mathrm{C}$. The cells were then rinsed up to 4 times with distilled water and stained with Alizarin Red S (40 mM; pH 4.2) for $10 \mathrm{~min}$ at room temperature. To remove excess dye, the cells were rinsed with distilled water prior to light microscopy analysis. Cells were analyzed under an Olympus IX71 inverted microscope using x10 objective (Olympus Corp., Tokyo, Japan).

Adipogenic differentiation analysis. $\mathrm{PPDMCs}\left(5 \times 10^{3}\right.$ cells $\left./ \mathrm{cm}^{2}\right)$ were seeded into Nunc ${ }^{\text {TM }} 4$-well dishes at passage 3 and treated with adipogenic differentiation medium composed of $10^{-6} \mathrm{M}$ dexamethasone, $60 \mu \mathrm{M}$ indomethacin, $500 \mu \mathrm{M}$ 3-isobutyl-1-methylxanthine (all from Sigma-Aldrich; Merck $\mathrm{KGaA}$ ), $5 \mu \mathrm{g} / \mathrm{ml}$ insulin (Biochrom $\mathrm{AG}$ ) and 10\% FBS in high-glucose DMEM for 21 days once cells had reached $80-90 \%$ confluence. The medium was replaced twice weekly. Oil red $\mathrm{O}$ staining was performed to visualize the presence of lipid droplets. Cells were fixed with $4 \%$ paraformaldehyde at room temperature for $10 \mathrm{~min}$, washed three times with distilled water and incubated with $60 \%$ isopropanol at room temperature for $10 \mathrm{~min}$. Subsequently, the cells were stained with $0.5 \%$ Oil Red O (Sigma-Aldrich; Merck KGaA) in isopropanol for $20 \mathrm{~min}$ at room temperature. Following staining, cells were washed with distilled water prior to light microscopy observations. Cells were analyzed under an Olympus IX71 inverted microscope using x10 objective (Olympus Corp.).

Colorectal cancer modeling and PDMC administration: In vivo experimental design. Experiments were performed using 38 4-month-old male albino Wistar rats, weighing 180-200 g, obtained from the Central Animal House of the Educational and Scientific Centre "Institute of Biology and
Medicine" of Taras Shevchenko National University of Kyiv (Kyiv, Ukraine). The animals were maintained under 12-h light/dark cycle, $60 \%$ humidity at $20-22^{\circ} \mathrm{C}$ and fed on standard diet and tap water ad libitum. DMH (Sigma-Aldrich; Merck $\mathrm{KGaA}$ ) was dissolved in saline and adjusted to $\mathrm{pH} 6.5$ with $2 \mathrm{M}$ sodium hydroxide immediately prior to use. To induce tumor development, rats were subcutaneously injected with $20 \mathrm{mg} / \mathrm{kg} \mathrm{DMH}$ in $0.1 \mathrm{ml}$ saline once weekly for 20 weeks $(n=26)$ as described previously (35). The control group $(n=8)$ received saline alone. PDMCs were injected at passage 3 into the rats following the formation of adenocarcinoma, equivalent to stage T1-2N0-1M0 of human colorectal cancer (35) at the beginning of week 22 , which was further determined following histological analysis of colon tumors.

Fig. 1 represents the treatment protocol. Group I $(n=4)$ received saline subcutaneously once a week for 20 weeks. At the start of week 22, rPDMCs from two donors were intravenously injected at a dose of $0.5 \times 10^{6}$ cells $/$ rat in $0.5 \mathrm{ml}$ saline. Group II $(n=4)$ received saline subcutaneously once a week for 20 weeks. At the start of week 22, human PDMCs (hPDMCs) from four donors were intravenously injected at a dose of $2 \times 10^{6}$ cells per rat in $0.5 \mathrm{ml}$ saline. Group III $(n=7)$ received DMH subcutaneously at a dose of $20 \mathrm{mg} / \mathrm{kg}$ once a week for 20 weeks and the rats were then maintained without supplements for 2 weeks of the experimental period. At the start of week 22, these rats (group III) were sacrificed to confirm tumor formation. Group IV $(n=3)$ received DMH subcutaneously at a dose of $20 \mathrm{mg} / \mathrm{kg}$ once a week for 20 weeks. At the start of week 22, the animals were injected with $0.5 \mathrm{ml}$ saline. Group V $(n=12)$ was treated similarly to group IV; however, at the start of week 22, rPDMCs from four donors were intravenously injected at a dose of $0.5 \times 10^{6}$ cells $/ \mathrm{rat}$ in $0.5 \mathrm{ml}$ saline. rPDMCs from the same donor were injected into three rats. Group VI $(n=4)$ was treated similarly to group IV; however, at the start of week 22, hPDMCs from four donors were intravenously injected at a dose of $2 \times 10^{6}$ cells $/ \mathrm{rat}$ in $0.5 \mathrm{ml}$ saline. Group VII $(n=4)$ received saline subcutaneously once a week for 20 weeks. At the start of week 22, $0.5 \mathrm{ml}$ saline was intravenously injected. Group III included a greater number of rats to increase the chance of obtaining an appropriate variance for statistical analysis of colon lesions at the early phase of DMH-induced carcinogenesis due to the low incidence of visible colon lesions. The number of rats in group $\mathrm{V}$ was extended to obtain an accurate analysis of carcinogenesis at the time of PDMCs administration. The rats in groups I, II, IV, V, VI and VII were sacrificed at the beginning of week 27, which was 5 weeks after PDMCs injection. This observation period was considered sufficient to evaluate the effect of cells on carcinogenesis (21).

Evaluation of colon lesions. The rats were sacrificed through carbon dioxide asphyxiation. Following this their abdomens were opened, and their entire gastrointestinal tracts were removed and sliced longitudinally. The colon lesions were defined macroscopically as nodules recognized throughout the entire colon. A ruler was placed next to the colon and the location of each tumor was recorded. A minimum of three images of the intestine fragments were obtained with the ruler. The size of the tissue lesions was calculated using ImageJ 1.46r (National Institutes of Health, Bethesda, MD, USA). The 


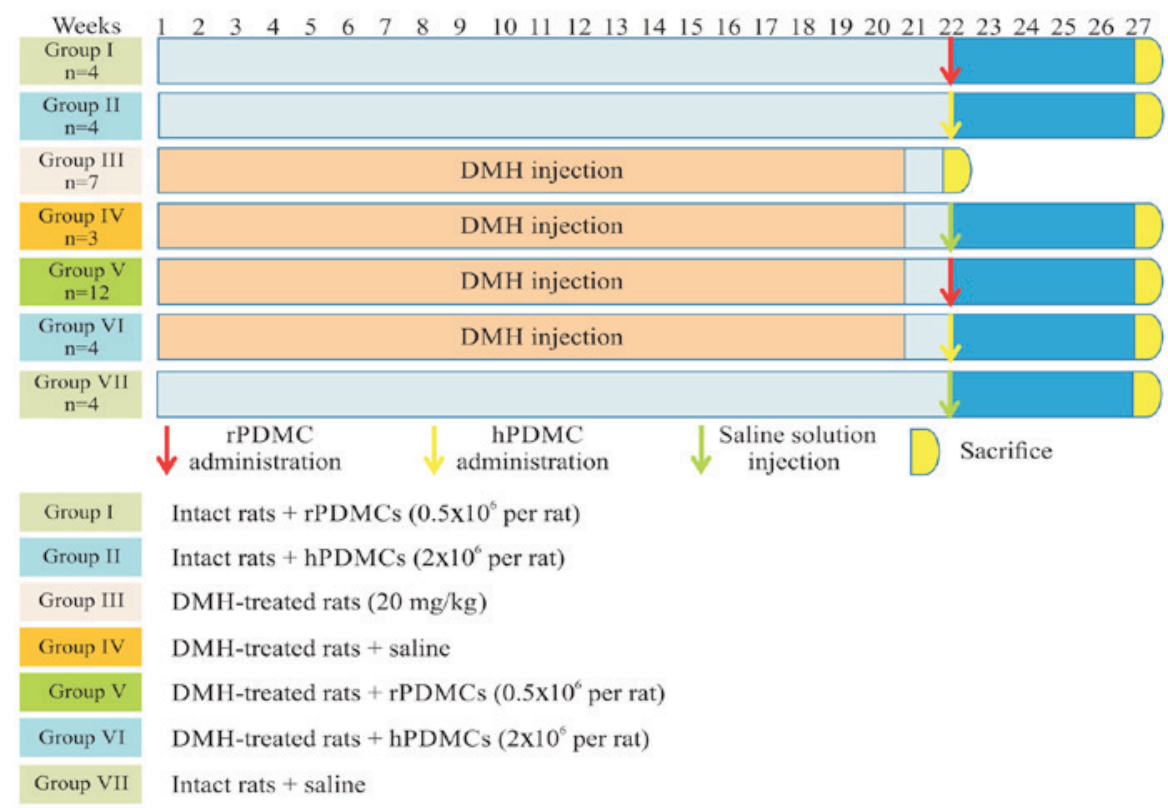

Figure 1. Treatment protocols for the various study groups. DMH, dimethylhydrazine; rPDMC, rat placenta-derived multipotent cells; hPDMC, human placenta-derived multipotent cells.

10-mm bar was set in each image, lesions were contoured and their area measured. The mean from the minimum of three images was calculated for each lesion. The total size of the colon lesions per rat was calculated as the sum of areas of all lesions in the colon. Tissue lesions were excised for histological analysis. The samples were fixed in $10 \%$ buffered formalin at $4^{\circ} \mathrm{C}$ for $24 \mathrm{~h}$ and embedded in paraffin, sliced into $5-\mu \mathrm{m}$ sections, stained with hematoxylin-eosin (Sigma-Aldrich; Merck KGaA) and examined under an Olympus CX-41 light microscope (Olympus Corp.) using x10 objective. Color microimages were obtained using an Olympus C-5050 Zoom Digital Camera (Olympus Corp.) and the aforementioned microscope.

Lungs, livers and spleens were excised from the rats of groups II, IV and VI, tumor tissue fragments from the rats of groups IV and VI, and colon tissue fragments from the rats of group II at week 5 following hPDMCs injection. Tissue fragments were stored in liquid nitrogen and at $-70^{\circ} \mathrm{C}$.

\section{Molecular biology methods}

Flow cytometry. For the immunophenotyping of rPDMCs at passage $3(n=4)$ the following fluorochrome-labeled monoclonal antibodies were used: PE mouse anti-rat cluster of differentiation (CD)90/mouse CD90.1 clone OX-7 (also known as OX7; 551401); APC-Cy7 mouse anti-rat CD45 clone OX-1 (561586) (both from BD Biosciences, Franklin Lakes, NJ, USA); and CD44 antibody (OX-50; GTX76381; GeneTex, Inc., Irvine, CA, USA), according to manufacturer's protocol. hPDMCs at passage $3(n=4)$ were stained with fluorescein isothiocyanate mouse anti-human CD90 clone 5E10 (555595), APC mouse anti-human CD44 clone G44-26 (also known as C26; 559942) and APC-Cy7 mouse anti-human CD45 clone 2D1 (557833; all from BD Biosciences). Cells were incubated with antibodies (dilution 1:100) for $30 \mathrm{~min}$ at $4^{\circ} \mathrm{C}$ in the dark. For CD29 assessment, a suspension of cells was washed and fixed in $2 \%$ buffered paraformaldehyde for $20 \mathrm{~min}$, permeabilized in $0.3 \%$ saponin for $30 \mathrm{~min}$ and stained with Integrin beta 1/CD29 antibody (EP1041Y; GTX61413; 1:50; GeneTex, Inc.) for $30 \mathrm{~min}$ (all steps were performed at $4^{\circ} \mathrm{C}$ ). Goat anti-rabbit immunoglobulin $(\mathrm{Ig}) \mathrm{G}(\mathrm{H}+\mathrm{L})$ secondary antibody with Alexa Fluor 405 conjugate, (A-31556; 1:700; Thermo Fisher Scientific, Inc., Waltham, MA, USA) was used as a secondary antibody and incubation occurred for $30 \mathrm{~min}$ at $4^{\circ} \mathrm{C}$ in the dark. Phenotyping was performed with a FACSAria III cell sorter using FACS Diva 6.1.2 software (both from BD Biosciences) for data analysis.

Immunofluorescence. hPDMCs $(\mathrm{n}=4)$ and rPDMCs $(\mathrm{n}=10)$ at passage 3 were washed with PBS, fixed and permeabilized in methanol-acetone $(1: 1)$ for $40 \mathrm{~min}$ at $-20^{\circ} \mathrm{C}$. The cells were then pre-incubated with $0.5 \%$ bovine serum albumin (BSA) in Dako Wash solution (Dako; Agilent Technologies, Inc., Santa Clara, CA, USA) at room temperature for $1 \mathrm{~h}$. Subsequently, cells were incubated at room temperature for $1 \mathrm{~h}$ with the following primary antibodies: Anti-caudal type homeobox 2 (CDX2) antibody (EPR2764Y; ab76541; 1:250); anti-TBR2/Eomesodermin (EOMES) antibody-ChIP grade (ab23345; all 1:500; Abcam, Cambridge, UK); goat anti-human vimentin polyclonal antibody (AB1620; 1:20; Merck KGaA); and cytokeratin, Pan Ab-1, mouse monoclonal antibody (MS-343-P1; 1:50; Thermo Fisher Scientific, Inc.). The cells were then washed three times with Dako Wash solution and incubated for $1 \mathrm{~h}$ at room temperature with the following secondary antibodies: Donkey anti-rabbit $\operatorname{IgG}(\mathrm{H}+\mathrm{L})$ secondary antibody with Alexa Fluor ${ }^{\circledR} 555$ conjugate (A-31572; 1:1,000); goat anti-mouse $\operatorname{IgG}(\mathrm{H}+\mathrm{L})$ secondary antibody with Alexa Fluor $^{\circledR} 488$ conjugate (A-11029; 1:1,000); and donkey anti-goat IgG $(\mathrm{H}+\mathrm{L})$ secondary antibody with Alexa Fluor ${ }^{\circledR} 488$ conjugate (A-11055; 1:700) (all from Thermo Fisher Scientific, Inc.). Following three washes with Dako Wash solution, the cells were analyzed under an Olympus IX71 inverted fluorescence microscope (Olympus Corp.) using x10 objective.

Reverse transcription-polymerase chain reaction $(R T-P C R)$. Total RNA from rPDMCs $(\mathrm{n}=10)$ and hPDMCs 
$(n=4)$ was isolated using AccuZol ${ }^{\mathrm{TM}}$ (Bioneer Corp., Daejeon, Korea), according to the manufacturer's instructions and stored at $-80^{\circ} \mathrm{C}$. Genomic DNA was removed using RNAse-free DNAse I treatment (Thermo Fisher Scientific, Inc.). A total of $1 \mathrm{mg}$ of total RNA was reverse-transcribed into cDNA using oligo $(\mathrm{dT})_{18}$ primers according to the RevertAid H Minus Reverse Transcriptase (Thermo Fisher Scientific, Inc.), according to the manufacturer's instructions. The primer sequences are presented in Table I. Glyceraldehyde-3-phosphate dehydrogenase $(G A D P H)$ and $\beta$-actin $(A C T B)$ were used as positive controls for cDNA synthesis for the materials of rat and human origin, respectively. RT-PCR reactions were performed on an Applied Biosystems 2720 thermal cycler (Applied Biosystems; Thermo Fisher Scientific, Inc.) to final volumes of $20 \mathrm{ml}$ containing $1 \mathrm{X}$ Hot Start PCR buffer (2,0 mM Mg $\left.{ }^{2+}\right), 0.2 \mathrm{mM}$ dNTPs, $0.3 \mu \mathrm{M}$ of each primer and 1.25 units of Maxima Hot Start Taq DNA polymerase (Thermo Fisher Scientific, Inc.). Each sample was assayed in triplicate, and each run included water blanks. PCR conditions were as follows: $95^{\circ} \mathrm{C}$ for $4 \mathrm{~min}$, followed by 40 cycles of $95^{\circ} \mathrm{C}$ for $30 \mathrm{sec}$. Annealing temperatures are listed in Table I and were performed for $20 \mathrm{sec}$ and followed by $72^{\circ} \mathrm{C}$ for 10-30 sec, with a final extension for $7 \mathrm{~min}$ at $72^{\circ} \mathrm{C}$. PCR products were analyzed using ethidium bromide stained $1 \%$ agarose gels electrophoresis. Weight Marker 'GeneRuler DNA Ladder Mix' (Thermo Fisher Scientific, Inc.) and the ladder were supplied with 6X DNA Loading Dye. Detection of the gel images was performed using a ChemiDoc XRS+ system (Bio-Rad Laboratories, Inc., Hercules, CA, USA).

$Y$ chromosome DNA detection. To establish the fate of injected hPDMCs, on day 35, PCR was completed to detect the human $\mathrm{Y}$ chromosome in different rat tissues, as previously described (37). Genomic DNA was extracted according to the standard phenol-chloroform extraction procedure with modifications (38). Tissue samples were homogenized in liquid nitrogen and lysed in buffer containing $50 \mathrm{mM} \mathrm{KCl}$, $50 \mathrm{mM}$ Tris- $\mathrm{HCl}$ (pH 8.0), $2.5 \mathrm{mM}$ EDTA, 0.45\% NP-40, $0.45 \%$ Tween-20. Lysates were incubated overnight at $55^{\circ} \mathrm{C}$ with Proteinase K $(100 \mu \mathrm{g} / \mathrm{ml}$; Thermo Fisher Scientific, Inc.), extracted twice with phenol and twice with chloroform. Genomic DNA was precipitated with 0.2 volume of ammonium acetate and two volumes of ethanol, followed by subsequent washing in $70 \%$ ethanol by centrifugation at $4^{\circ} \mathrm{C}$ for $15 \mathrm{~min}$ at $10,000 \mathrm{~g}$ and pellet dissolution in Tris-EDTA buffer. Extracted DNA was stored at $-20^{\circ} \mathrm{C}$ once the concentration evaluation was performed using NanoDrop 2000 (Thermo Fisher Scientific, Inc.). The quality of the isolated DNA was verified by PCR for the $\beta$-actin gene. Human DNA of injected PDMCs was verified to contain the human $\mathrm{Y}$ chromosome following PCR using the Quantifiler ${ }^{\mathrm{TM}}$ Y Human Male DNA Quantification kit (Applied Biosystems; Thermo Fisher Scientific, Inc.) which contained AmpliTaq Gold ${ }^{\circledR}$ DNA Polymerase and primers/probe mixture, according to manufacturer's protocol (39).

Fluorescence in situ hybridization (FISH). The fetal origin of rPDMCs $(n=3)$ at passage 3 was confirmed through FISH using Chromosome Y-green and Chromosome X-orange XCyting Rat Chromosome Painting Probes (D-1521-050-OR and D-1522-050-FI; MetaSystems, Heidelberg, Germany), according to the manufacturer's protocol. FISH analysis of
hPDMCs at passage $3(n=3)$ was performed using a Vysis CEP X SpectrumOrange/Y SpectrumGreen Direct Labeled Fluorescent DNA Probe kit (Abbott Molecular, Inc., Abbott Park, IL, USA), according to the manufacturer's protocol. The nuclei were counterstained with $10 \mu$ l DAPI and observed under an Axio Imager M1 fluorescence microscope (magnification, x100; Carl Zeiss AG, Oberkochen, Germany). A total of 500 cells/slide were analyzed. Microimages were obtained using a ProgRes MF Camera (Jenoptik, Jena, Germany) and the aforementioned microscope.

Immunohistochemistry. Following hPDMCs administration, colon and tumor tissue fragments from intact (group II; $\mathrm{n}=4$ ) and DMH-treated rats (group VI; n=4) were fixed in $10 \%$ buffered formalin at $4^{\circ} \mathrm{C}$ for $24 \mathrm{~h}$, embedded in paraffin and sectioned on 5- $\mu \mathrm{m}$ thick slices using Microm HM325 microtome (Carl Zeiss AG). Paraffin-embedded tissues were deparaffinized in $100 \%$ xylene two times for 5 min each and rehydrated in decreasing concentrations of ethanol: 96, 70 and $50 \%$. Slides were boiled in Tris-EDTA buffer $(10 \mathrm{mM}$ Tris and $1 \mathrm{mM}$ EDTA; $\mathrm{pH} 9.0$ ) for $30 \mathrm{~min}$ to retrieve the antigen. Nonspecific reactivity was reduced by incubating tissue sections in a blocking solution (0.1 M PBS with $0.5 \%$ BSA) at room temperature for $30 \mathrm{~min}$. Immunostaining was completed following an overnight incubation at $4{ }^{\circ} \mathrm{C}$ with anti-mitochondria primary antibody that binds with the surface of intact mitochondria (clone 113-1; MAB1273; 1:100; Merck $\mathrm{KGaA}$ ). Following washing three times for $10 \mathrm{~min}$ each with $0.1 \mathrm{M}$ PBS, samples were incubated with goat anti-mouse IgG $(\mathrm{H}+\mathrm{L})$ secondary antibody with Alexa Fluor 488 conjugate (A-11029; 1:1,000; Thermo Fisher Scientific, Inc.) for $1 \mathrm{~h}$ at room temperature in the dark. Following nuclear staining with Hoechst 33342 (H3570; 1:5,000; Thermo Fisher Scientific, Inc.), slides were mounted using Mowiol 4-88 (Sigma-Aldrich; Merck KGaA). Confocal analysis was performed using a Zeiss LSM 510 Meta microscope (magnification, x63) and images were captured with Zeiss LSM Image Browser Version 4.2.0.121 software (all from Carl Zeiss AG).

Statistical analysis. Statistical analysis was performed using Statistica 8.0 (StatSoft, Inc., Tulsa, OK, USA). The results of FACS expression assays for CD90, CD44, CD45 and CD29 were presented as the median and range. Analysis of the number and size of colon lesions was performed using Kruskal-Wallis tests for comparison of multiple groups followed by Dunn's test for comparison of two groups. $\mathrm{P}<0.05$ was considered to represent a statistically significant difference.

\section{Results}

Characterization of rat and human PDMCs. On PDMC culture days 7-14, the placental tissue fragments became attached and cells migrated from the tissue and adhered to the plastic surface. A number of the morphologically distinct cell populations emanated from the tissue and, at passage 0 , possessed extreme heterogeneity. Outgrown colonies obtained from the rat and human placenta were formed by spindle- or round-shaped cells (Fig. 2). Rat placental outgrowth from one or more colony types formed stellate-shaped cells (Fig. 2B) with numerous inclusions. Human placental outgrowth did not form colonies of stellate-shaped cells; however, single 






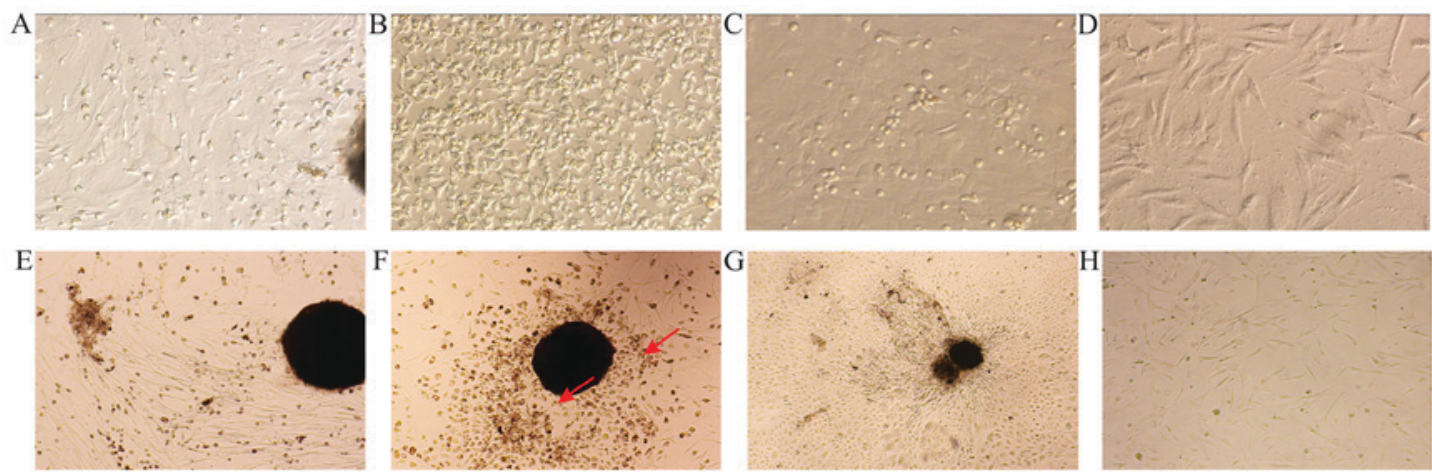

Figure 2. Morphological characteristics of $\operatorname{PDDMC}(\mathrm{n}=10)$ and hPDMC $(\mathrm{n}=4)$ cultures were determined using phase-contrast microscopy. (A) Spindle-shaped, (B) stellate-shaped and (C) round-shaped migrating rPDMC colonies at passage 0. (D) rPDMCs at the 2nd passage. (E) Spindle-shaped, (F) mixed-shaped with single stellate cells (red arrows) and (G) round-shaped migrating hPDMCs colonies at passage 0 . (H) hPDMCs at the 2nd passage. A, B, C and D: Magnification, x100; E, F, G and H: Magnification, x50. rPDMC, rat placenta-derived multipotent cells; hPDMC, human placenta-derived multipotent cells.
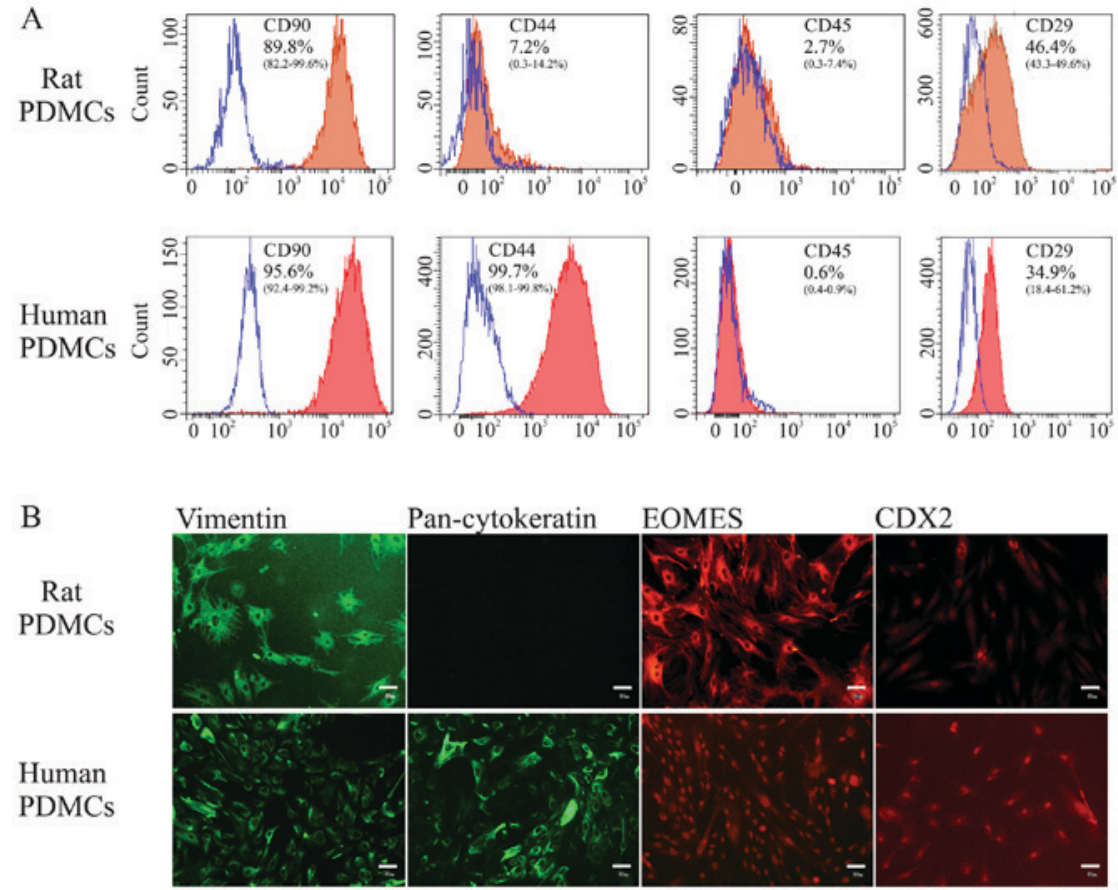

Figure 3. Characteristics of PDMCs. (A) Expression of surface markers on rat and human PDMCs at passage 3. Cells stained with the corresponding antibodies are indicated by filled brown histograms; negative isotype controls are indicated by open blue histograms. The data are presented as the median and range $(\% ; n=4)$. (B) Fluorescent immunocytochemical staining (representative data) of rat $(n=10)$ and human $(n=4)$ PDMCs at passage 3 for vimentin $($ green), pan-cytokeratin (green), EOMES, and CDX2 (both red). Scale bar, $50 \mu \mathrm{m}$. PDMCs, placenta-derived multipotent cells; CD, cluster of differentiation; EOMES, eomesodermin; CDX2, caudal type homeobox 2.

stellate-shaped cells were present in a number of colonies (Fig. 2F). Subculturing human and rat PDMCs resulted in spindle-shaped cells in a homogenous monolayer formation, whereas stellate and round cells did not anchor to the plastic surface following trypsinization (Fig. 2D and H).

Flow cytometry analysis of rPDMCs at passage 3 indicated that all cells were $\mathrm{CD} 90^{+}, \mathrm{CD} 45^{-}$and heterogeneous for $\mathrm{CD} 29$ and CD44. hPDMCs were CD90 ${ }^{+}, \mathrm{CD} 44^{+}$, partially CD29 ${ }^{+}$ and CD45- (Fig. 3A). rPDMCs expressed vimentin but not pan-cytokeratin; however, expression of both was detected in hPDMCs. mRNA of EOMES and CDX2 transcription factors, which are critical for trophoblast and mesoderm development, were revealed in PDMCs of both origins. Notably, expression of EOMES was characterized primarily by cytoplasmic or nuclear localization in rPDMCs and hPDMCs, respectively (Fig. 3B).

The results of the present study revealed the presence of CDX2, EOMES, inhibitor of DNA binding 2 (ID2), and POU class 5 Homeobox 1 (POU5F1) mRNA in hPDMCs and CDX2, ID2 and POU5F1 mRNA in rPDMCs by RT-PCR (Fig. 4A). Nanog expression was not detected in rPDMCs (Fig. 4A). Furthermore, the syncytial trophoblast and trophoblast giant cell gene, prolactin family 3 , subfamily b, member 1 (Prl3b1) and spongiotrophoblast-specific gene (trophoblast specicific protein $\alpha$; Tpbpa) expression were not observed in rPDMCs. Absence of these mRNA, specific for differentiated trophoblast 


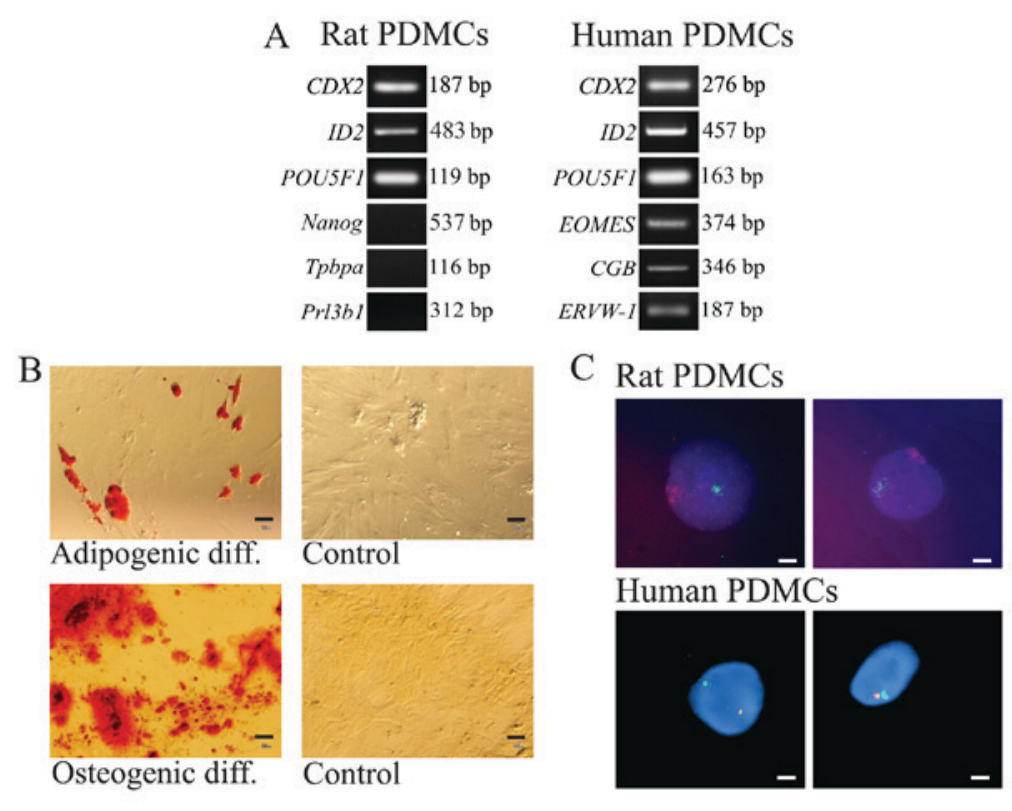

Figure 4. Characteristics of PDMCs. (A) Representative data of reverse transcription- polymerase chain reaction analysis of rat ( $\mathrm{n}=10)$ and human $(\mathrm{n}=4)$ PDMCs for stemness- and trophoblast-related transcripts. (B) Differentiation of rat PDMCs into multiple lineages. Adipogenic differentiation is demonstrated by the accumulation of intracellular lipid droplets stained by Oil Red O. Osteogenic differentiation is demonstrated by the deposition of extracellular calcium visualized through Alizarin Red S staining. Negative control cells were grown in Dulbecco's modified Eagle medium supplemented with $10 \%$ fetal bovine serum; no Alizarin Red S or Oil Red O staining was observed. Scale bar, $50 \mu \mathrm{m}$. (C) Representative data of fluorescence in situ hybridization analysis of rat $(\mathrm{n}=3)$ and human $(\mathrm{n}=3)$ PDMCs at the 3rd passage for X (orange)/Y (green) chromosome. Scale bar, $10 \mu \mathrm{m}$. PDMCs, placenta-derived multipotent cells; CDX2, caudal type homeobox 2; ID2, inhibitor of DNA binding 2; POU5F1, POU class 5 homeobox 1; Tpbpa, trophoblast specific protein $\alpha$; Prl3b1, prolactin family 3 , subfamily b, member 1; EOMES, eomesodermin; CGB, choriogonadotropin subunit- $\beta$; ERVW-1, endogenous retrovirus group W envelope member 1.
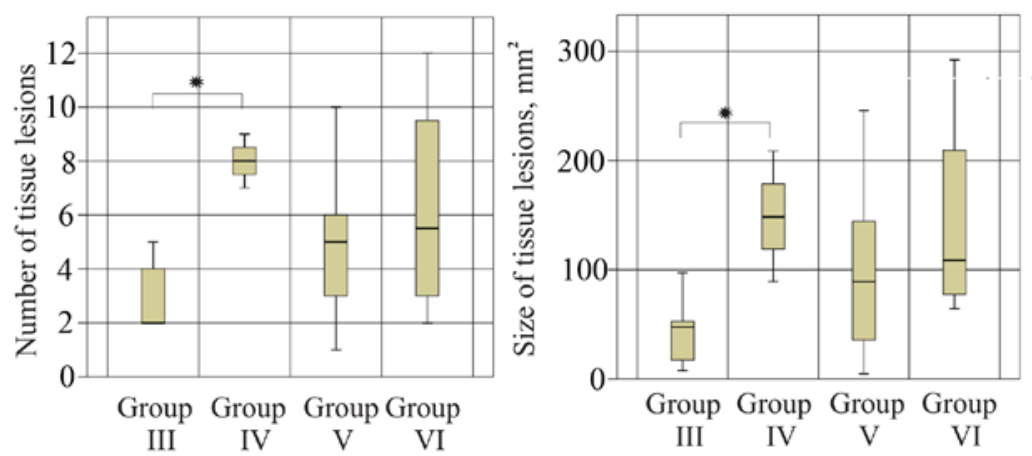

Figure 5. Effect of the administration of PDMCs on the number and size of DMH-induced colon tissue lesions. Comparative analysis between groups was completed using a Kruskal-Wallis test for comparison of multiple groups followed by Dunn's test for comparison of two groups. The data represent the median and interquartile range. The error bars represent the $95 \%$ confidence interval. " $\mathrm{P}<0.05$ as indicated. Group III, DMH, 22 weeks (baseline), $\mathrm{n}=7$; group IV, DMH, 27 weeks, n=3; Group V, DMH, rat PDMC transplantation, n=12; Group VI, DMH, human PDMC transplantation, n=4; PDMC, placenta-derived multipotent cells; DMH, dimethylhydrazine.

cells, indicated that the rPDMCs were not contaminated with a trophoblast cell population. hPDMCs expressed both genes of stemness, including CDX2, EOMES, POU5F1, ID2, and trophoblast-specific genes, choriogonadotropin subunit- $\beta$ (CGB) and endogenous retrovirus group W envelope member 1 (ERVW-1; also known as Syncytin-1; Fig. 4A).

The successful induction of adipogenic differentiation was observed in all rPDMC samples $(n=7)$, whereas osteogenic differentiation was observed in only 3 of the 7 samples (Fig. 4B). The present study hypothesized that Alizarin S staining was not sufficiently sensitive to detect differentiation and that the differentiation capacity may be detected using PCR analysis.
The mammalian placenta is composed of both fetal and maternal components. The fetal origin of rPDMCs and hPDMCs was confirmed by the presence of the Y chromosome via FISH analysis (Fig. 4C).

Intravenous transplantation of PDMCs. PDMCs were intravenously transplanted into rats at week 22 following the initiation of carcinogenesis. At this time, each rat exhibited at least one adenocarcinoma with histopathological alterations (dysplasia/hyperplasia) of the colon epithelium. The number and size of tissue lesions increased significantly in control rats (group IV) compared with group III at 5 weeks ( $<<0.05$; Fig. 5). However, these parameters were not significantly decreased 
Table II. Detection of human Y chromosome in different organs following transplantation with hPDMCs.

Tissue type

\begin{tabular}{|c|c|c|c|c|c|}
\hline \multirow[b]{3}{*}{ Group } & \multirow{2}{*}{\multicolumn{2}{|c|}{ Colon }} & & & \\
\hline & & & \multirow[b]{2}{*}{ Liver } & \multirow[b]{2}{*}{ Spleen } & \multirow[b]{2}{*}{ Lung } \\
\hline & Tumor tissue & Normal tissue & & & \\
\hline (VI) DMH-treated rats + hPDMCs & $3 / 3$ & NA & $4 / 4$ & $2 / 4$ & $2 / 3$ \\
\hline (IV) DMH-treated rats + saline & $0 / 3$ & NA & NA & NA & NA \\
\hline (II) Intact rats + hPDMCs & NA & $3 / 3$ & $3 / 3$ & $3 / 3$ & $3 / 3$ \\
\hline
\end{tabular}

Data are presented as the number of rats with positive signal/all rats. In Group VI, the colon normal tissue was not examined due to the necessity to study engraftment capacity of cells in tumors. Group IV was used as a reference for tumors of Group VI; as there were no cells detected in tumors, there was no need to examine the rest of organs. In the intact rats from Group II, no tumors were present; therefore, these groups were not analyzed. hPDMC, human placenta-derived multipotent cells; NA, sample not available or not adequate for analysis, DMH, dimethylhydrazine.

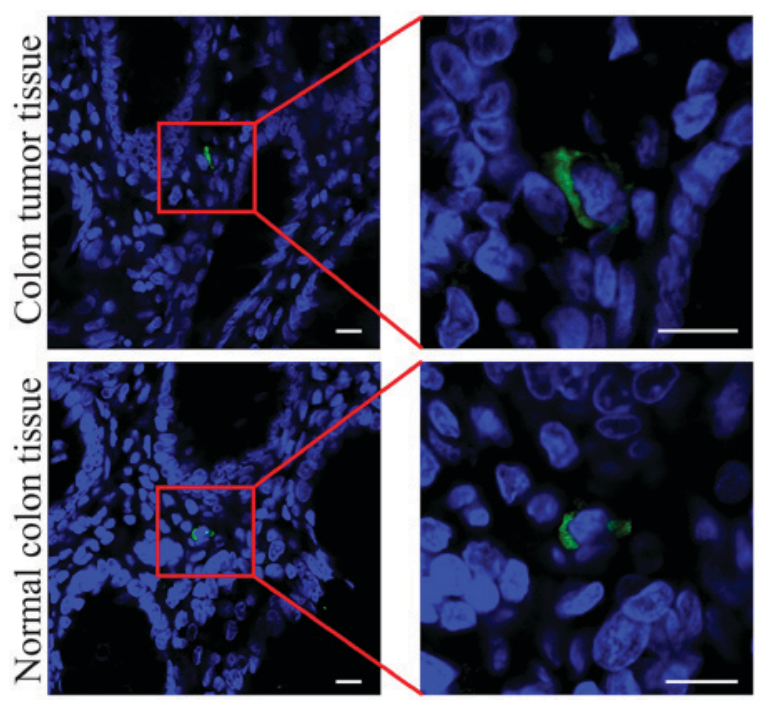

Figure 6. Human placenta-derived multipotent cells identified in rat normal and tumor colon tissues by human-mitochondrial staining. Immunohistochemistry fluorescence: Anti-human mitochondria are green, nuclei are blue. Scale bar, $10 \mu \mathrm{m}$; magnification, x630.

in the PDMC-treated group (V) compared with the control group (IV; Fig. 5).

Engraftment potential of PDMCs. PCR detection of the human Y chromosome demonstrated a high distribution level of hPDMCs in different tissues. The human Y chromosome was detected in the normal and cancer-induced colon, liver, spleen and lung 5 weeks after transplantation (Table II). Additionally, living human mitochondria in engraftment hPDMCs were visualized by immunohistochemistry in normal and tumor colon tissues of rats from group II $(n=3)$ and group VI $(n=3)$, respectively (Fig. 6). hPDMCs were localized in the submucosa or connective tissue of crypts.

\section{Discussion}

In the present study, rat and human PDMCs were characterized and it was demonstrated that they share similar surface immunophenotypes, with the exception of a lower expression of CD44 in rPDMCs. Furthermore, it has previously been demonstrated that hPDMCs express CD73 and CD105, but not CD34 or CD14 (40) and differentiated into osteogenic, adipogenic and chondrogenic lineages (41), thus fulfilling the minimal criteria for multipotent MSCs (42). Despite the absence of a classic mesenchymal surface immunophenotype (42), rPDMCs possessed the ability to differentiate into mesodermal cell lineages (adipogenic and osteogenic). In addition, human and rat PDMCs have a fetal origin and do not contain maternal decidual cells. The low osteogenic capacity of rPDMCs is similar to features observed in hPDMCs $(41,43,44)$. By contrast to human, rPDMCs did not express pan-cytokeratin in the present study. Although cytokeratin is an epithelial marker, it has previously been detected in human umbilical cord-derived MSCs (45) and in bovine extraembryonic mesoderm cells following 1 week of culture (46). The surface immunophenotype of rPDMCs differ from hPDMCs as CD44 was expressed at a low level in rat cells. Notably, CD44- cells from human and mouse bone marrow are primary mesenchymal stem cell populations $(47,48)$. CDX2, EOMES, POU5F1 and ID2 were common for rPDMCs and hPDMCs. Homeobox gene, CDX2, is critical for the development of the caudal part of the mouse embryo, including all extraembryonic tissues such as trophectoderm, endoderm and mesoderm (49-51). EOMES is involved in regulating the development of different cell types, specifically endoderm cells, cardiac mesoderm and T-lymphoid cells (52-55). POU5F1 is involved in the maintenance of pluripotency in embryonic stem cells $(56,57)$, and is also necessary for the development of the endoderm (58), ectoderm (59), specifically trophectoderm (60), and mesoderm (61) in the mouse embryo. Furthermore, expression of POU5F1 in hPDMCs has previously been demonstrated (62). ID2 expression is common for human (63) and rat (64) trophoblast progenitors. In turn, human cytotrophoblasts transiently downregulate the protein expression of ID2 as they differentiate and invade in situ (63). In mice and rats, pre-implantation embryo ID2 is expressed in the chorion ectoderm, this expression is lost during the differentiation of trophoblast stem cells into a number of different trophoblast subpopulations $(65,66)$. However, ID2 
was identified in mouse BM-MSCs and was demonstrated to be involved in osteogenesis (67). Consequently, the role of ID2 in both rPDMCs and hPDMCs remains controversial. In the present study, hPDMCs expressed trophoblast-associated genes, CGB and ERVW-1; however, Prl3b1 and Tpbpa were not detected in rPDMCs. Ectoplacental cones, spongiotrophoblasts and glycogen trophoblast cells are characterized by the expression of Tpbpa (68-71). Tpbpa is strictly specific to rodents and orthologs of this gene are absent in humans (72). Prl3b1 is inherent to rat multiple trophoblast giant cell subtypes (73). CGB and ERVW-1 are recognized as markers of human syncytiotrophoblast (74). Therefore, hPDMCs express several trophoblast-associated genes in comparison to rat ones. Thus, rPDMCs possess immunophenotype and differentiation potential inherent in MSCs; however, in contrast to hPDMCs, have low expression of CD44 and do not express trophoblast-associated genes.

Due to contradictory studies regarding the growth, promotion and suppression of cancer cells, the application of MSCs as an antitumor therapeutic is currently uncertain. Furthermore, MSCs, specifically PDMCs, have an immunosuppressive capacity. They actively suppress $\mathrm{CD} 4^{+} \mathrm{T}$-helper and $\mathrm{CD}^{+}$cytotoxic T-lymphocytes $(44,75)$, dendritic and $\mathrm{B}$ cell function $(76,77)$, inhibit the maturation of monocytes into dendritic cells (78) and induce Treg population (79). PDMCs produce a number of anti-inflammatory molecules, including interleukin (IL)-10, IL-6, transforming growth factor $\beta$, hepatocyte growth factor and prostaglandin E2 (79). Furthermore, PDMCs do not cause lymphocyte proliferation induced by alloantigens or through $\mathrm{T}$ cell receptor cross-linking (80). The present study hypothesized that the immunosuppressive effect of PDMCs in rats does not prevent cancer progression, thus explaining the lack of significant effects of these cells on colon tumor growth at middle/late stages in the present experiments. However, low immunogenicity and high immunosuppressive properties may explain the long-term survival of allogeneic and xenogeneic PDMCs (81).

Accordingly, the concentration of transplanted MSCs should be selected more precisely in accord with the model of transplantation. The present study transplanted rPDMCs at a lower dose $\left(0.5 \times 10^{6}\right.$ cells/rat $)$ in comparison to BM-MSC transplantations: $4 \times 10^{6}$ cells/rat $(21), 20 \times 10^{6}$ cells/rat (23) or $1 \times 10^{6}$ cells/mouse (given a mouse weight of $\left.30 \mathrm{~g}\right)(22,82)$. The dose of $0.5 \times 10^{6} \mathrm{rPDMCs} / \mathrm{rat}$ corresponds to $1-2$ million cells $/ \mathrm{kg}$, which is commonly used in clinical practice (83). A study by Katsuno et al (21) demonstrated the tumor suppressive properties of MSCs in DMH-induced oncogenesis were present in mice in the early phase (week 5) prior to tumor occurrence, but not in the late phase (week 15). These data are consistent with the observations of the present study, where an absence of significant effect of rPDMCs on formed tumor growth was demonstrated.

The present study demonstrated that intravenously-injected hPDMCs exhibited high engraftment efficiency and prolonged survival in normal and cancer-induced colon tissue along with liver, spleen and lung tissue for 35 days following administration. Additionally, the results of the present study demonstrated the presence of administrated hPDMCs in normal and malignant colon tissue using immunohistochemistry with the anti-human mitochondria antibody. However, the present study did not observe any effect on colon tumor growth and therefore, it may be suggested that the primary physiological effect should be expected much later. The results of the present study are in accordance with other studies that detected the human placental deciduas basalis-derived MSCs in the lung, liver, spleen, stomach and left femur marrow following cell transplantation into nude mice during the whole observation period (up to 30 days) (84). Additionally, positive staining for anti-human mitochondria was identified in bone marrow, lung and liver tissues on day 30 (84). Furthermore, the presence of allogeneic and xenogeneic fetal membrane-derived cells has been demonstrated to remain in the lungs for 14 days following intraperitoneal transplantation (85). Human placental MSCs transplanted into a pig via the portal vein were detected in the liver for $<156$ days (86).

With the exception of the lungs, the expression of hPDMCs was slightly detectable in SCID-rab murine organs 7 days after cell transplantation by bioluminescence live imaging ex vivo (27). Furthermore, only a few transplanted cells were identified in the bone (27). By contrast, a number of studies have demonstrated a therapeutic effect without a high level of transplanted cell engraftment in myocardial tissue $(80,87,88)$. Short-term engraftment of intravenously administered MSCs is enough to modulate the myocardial tissue repair following infarction by secreting the tumor necrosis factor-inducible gene 6 protein $(89,90)$. Furthermore, the therapeutic effect of MSCs may be caused by high immunomodulatory properties, rather than by direct differentiation into tissue-specific cells (91).

In conclusion, the present study demonstrated that rPDMCs and hPDMCs possess similar immunophenotypes, with the exception of trophoblast-associated gene expression being identified in hPDMCs only. Allogeneic intravenous transplantation of PDMCs into rats with $\mathrm{DMH}$-induced colorectal carcinogenesis in the mid and late stages of the disease had no effect on continued tumor growth. No marked effect on tumor progression was observed 35 days following administration. Additionally, hPDMCs engraft in different organs, including the liver, spleen, lung and normal or cancer-induced colon.

Further studies may indicate the effect of allogeneic intravenous transplantation of PDMCs in the middle and late phases of colon carcinogenesis on the degree of both differentiation and invasion of colon tumors. Since colon carcinogenesis is very heterogeneous, further detailed study of the characteristics of the influence of PDMCs on the progression of different types of tumors is required.

\section{Acknowledgements}

The authors of the present study thank Mr S. Martynenko and Dr M.Sokolov for helping to organize and supporting this research, Dr Zh. Misharina for assistance and education of FISH assay, and Dr D. Miroshnychenko, Dr S. Palchevskyy and Dr R. Svitin for help in preparing this manuscript. The authors acknowledge the help of Dr Natalia Schlabritz-Lutsevich for providing substantial comments on the final draft and Ms Melissa Waggoner for her help with the manuscript editing. The present study was supported by the Institute of Cell Therapy and The National Academy of Science of Ukraine (grant no. 0114U003877; Kyiv, Ukraine). 


\section{References}

1. Melmed GY, Pandak WM, Casey K, Abraham B, Valentine J, Schwartz D, Awais D, Bassan I, Lichtiger S, Sands B, et al: Human placenta-derived Cells (PDA-001) for the treatment of moderate-to-severe Crohn's disease: A phase 1b/2a study. Inflamm Bowel Dis 21: 1809-1816, 2015.

2. Liang J, Zhang H, Wang D, Feng X, Wang H, Hua B, Liu B and Sun L: Allogeneic mesenchymal stem cell transplantation in seven patients with refractory inflammatory bowel disease. Gut 61: 468-469, 2012.

3. Duijvestein M, Vos ACW, Roelofs H, Wildenberg ME, Wendrich BB, Verspaget HW, Kooy-Winkelaar EM, Koning F, Zwaginga JJ, Fidder $\mathrm{HH}$, et al: Autologous bone marrow-derived mesenchymal stromal cell treatment for refractory luminal Crohn's disease: Results of a phase I study. Gut 59: 1662-1669, 2010.

4. Onken J, Gallup D, Hanson J, Pandak M and Custer LP: Successful outpatient treatment of refractory Crohn's disease using adult mesenchymal stem cells. In: American College of Gastroenterology. Annual Meeting, Las Vegas, LV, 2006.

5. Siegel R, Desantis C and Jemal A: Colorectal cancer statistics, 2014. CA Cancer J Clin 64: 104-117, 2014.

6. American Cancer Society: Colorectal Cancer Facts and Figures 2014-2016. Color Cancer Facts Fig: 1-32, 2014.

7. Altobelli E, D'Aloisio F and Angeletti PM: Colorectal cancer screening in countries of European Council outside of the EU-28. World J Gastroenterol 22: 4946-4957, 2016.

8. Chen D, Liu S, Ma H, Liang X, Ma H, Yan X, Yang B, Wei J and Liu X: Paracrine factors from adipose-mesenchymal stem cells enhance metastatic capacity through Wnt signaling pathway in a colon cancer cell co-culture model. Cancer Cell Int 15: 42 , 2015.

9. Ohta N, Ishiguro S, Kawabata A, Uppalapati D, Pyle M, Troyer D, De S, Zhang Y, Becker KG and Tamura M: Human umbilical cord matrix mesenchymal stem cells suppress the growth of breast cancer by expression of tumor suppressor genes. PLoS One 10: e0123756, 2015.

10. Zheng H, Zou W, Shen J, Xu L, Wang S, Fu YX and Fan W: Opposite effects of coinjection and distant injection of mesenchymal stem cells on breast tumor cell growth. Stem Cells Trans Med 5: 1216-1228, 2016.

11. Secchiero P, Zorzet S, Tripodo C, Corallini F, Melloni E, Caruso L, Bosco R, Ingrao S, Zavan B and Zauli G: Human bone marrow mesenchymal stem cells display anti-cancer activity in SCID mice bearing disseminated non-hodgkin's lymphoma xenografts. PLoS One 5: e11140, 2010.

12. Dasari VR, Velpula KK, Kaur K, Fassett D, Klopfenstein JD Dinh DH, Gujrati M and Rao JS: Cord blood stem cell-mediated induction of apoptosis in glioma downregulates X-linked inhibitor of apoptosis protein (XIAP). PLoS One 5: e11813, 2010

13. Cousin B, Ravet E, Poglio S, De Toni F, Bertuzzi M, Lulka H, Touil I, André M, Grolleau JL, Péron JM, et al: Adult stromal cells derived from human adipose tissue provoke pancreatic cancer cell death both in vitro and in vivo. PLoS One 4: e6278, 2009.

14. Qiao L, Xu Z, Zhao T, Zhao Z, Shi M, Zhao RC, Ye L and Zhang X: Suppression of tumorigenesis by human mesenchymal stem cells in a hepatoma model. Cell Res 18: 500-507, 2008.

15. Qiao L, Xu ZL, Zhao TJ, Ye LH and Zhang XD: Dkk-1 secreted by mesenchymal stem cells inhibits growth of breast cancer cells via depression of Wnt signalling. Cancer Lett 269: 67-77, 2008.

16. Khakoo AY, Pati S, Anderson SA, Reid W, Elshal MF, Rovira II, Nguyen AT, Malide D, Combs CA, Hall G, et al: Human mesenchymal stem cells exert potent antitumorigenic effects in a model of Kaposi's sarcoma. J Exp Med 203: 1235-1247, 2006.

17. Antony AK, Rodby K, Tobin MK, O'Connor MI, Pearl RK, DiPietro LA, Breidenbach WC and Bartholomew AM: Composite tissue allotransplantation and dysregulation in tissue repair and regeneration: A role for mesenchymal stem cells. Front Immunol 4: 188, 2013

18. Harding J, Roberts RM and Mirochnitchenko O: Large animal models for stem cell therapy. Stem Cell Res Ther 4: 23, 2013

19. Isakova IA, Lanclos C, Bruhn J, Kuroda MJ, Baker KC, Krishnappa V and Phinney DG: Allo-reactivity of mesenchymal stem cells in rhesus macaques is dose and haplotype dependent and limits durable cell engraftment in vivo. PLoS One 9 e87238, 2014.
20. Lévêque $X$, Mathieux E, Nerrière-Daguin V, Thinard R, Kermarrec L, Durand T, Haudebourg T, Vanhove B, Lescaudron L, Neveu I and Naveilhan P: Local control of the host immune response performed with mesenchymal stem cells: Perspectives for functional intracerebral xenotransplantation. J Cell Mol Med 19: 124-134, 2015.

21. Katsuno T, Ochi M, Tominaga K, Tanaka F, Sogawa M, Tanigawa $T$, Yamagami $H$, Shiba $M$, Watanabe $K$, Watanabe T, et al: Mesenchymal stem cells administered in the early phase of tumorigenesis inhibit colorectal tumor development in rats. J Clin Biochem Nutr 53: 170-175, 2013.

22. Chen Z, He X, He X, Chen X, Lin X, Zou Y, Wu X and Lan P: Bone marrow mesenchymal stem cells ameliorate colitis-Associated tumorigenesis in mice. Biochem Biophys Res Commun 450: 1402-1408, 2014

23. Nasuno M, Arimura Y, Nagaishi K, Isshiki H, Onodera K, Nakagaki S, Watanabe S, Idogawa M, Yamashita K, Naishiro Y, et al: Mesenchymal stem cells cancel azoxymethane-induced tumor initiation. Stem Cells 32: 913-925, 2014.

24. Djouad F, Bony C, Apparailly F, Louis-Plence P, Jorgensen C and Noël D: Earlier onset of syngeneic tumors in the presence of mesenchymal stem cells. Transplantation 82: 1060-1066, 2006.

25. Zhao G and Wang Y: Umbilical Cord Mesenchymal Stem Cells Infusion for Ulcerative Colitis, 2010.

26. Marwitz S, Zeiser T, Schultz H, Kähler D, Abdullah M, Hauber HP, Zabel P, Vollmer E and Goldmann T: The human placenta releases substances that drive lung cancer into apoptosis. Diagn Pathol 4: 27, 2009.

27. Li X, Ling W, Pennisi A, Wang Y, Khan S, Heidaran M, Pal A, Zhang X, He S, Zeitlin A, et al: Human placenta-derived adherent cells prevent bone loss, stimulate bone formation, and suppress growth of multiple myeloma in bone. Stem Cells 29: 263-273, 2011.

28. Zheng L, Zhang D, Chen X, Yang L, Wei Y and Zhao X: Antitumor activities of human placenta-derived mesenchymal stem cells expressing endostatin on ovarian cancer. PLoS One 7: e39119, 2012.

29. Chen Q, Cheng P, Song N, Yin T, He H, Yang L, Chen X and Wei Y: Antitumor activity of placenta-derived mesenchymal stem cells producing pigment epithelium-derived factor in a mouse melanoma model. Oncol Lett 4: 413-418, 2012.

30. Yang HT and Chao KC: Foetal defence against cancer: A hypothesis. J Cell Mol Med 17: 1096-1098, 2013

31. Tartakover-Matalon S, Mizrahi A, Epstein G, Shneifi A, Drucker L, Pomeranz M, Fishman A, Radnay J and Lishner M: Breast cancer characteristics are modified by first trimester human placenta: In vitro co-culture study. Hum Reprod 25: 2441-2454, 2010.

32. Pavlidis N and Pentheroudakis G: Metastatic involvement of placenta and foetus in pregnant women with cancer. Recent Results Cancer Res 178: 183-194, 2008.

33. Wooding P and Burton G: Comparative placentation: Structures, functions and evolution, 2008.

34. Telugu BP and Green AJ: Comparative placentation. In: Comparative Reproductive Biology. Constantinescu G and Schatten H (eds). Blackwell Publishing, Ames, IA, pp271-319, 2007.

35. Perše $\mathrm{M}$ and Cerar A: Morphological and molecular alterations in 1,2 dimethylhydrazine and azoxymethane induced colon carcinogenesis in rats. J Biomed Biotechnol 2011: 473964, 2011.

36. Suman S, Fornace AJ Jr and Datta K: Animal models of colorectal cancer in chemoprevention and therapeutics development. In: Colorectal Cancer - From Prevention to Patient Care. Ettarch R (ed). InTech, pp277-300, 2012.

37. Cheng K and Gupta S: Quantitative tools for assessing the fate of xenotransplanted human stem/progenitor cells in chimeric mice. Xenotransplantation 16: 145-151, 2009.

38. Miller SA, Dykes DD and Polesky HF: A simple salting out procedure for extracting DNA from human nucleated cells. Nucleic Acids Res 16: 1215, 1988.

39. Green RL, Roinestad IC, Boland C and Hennessy LK: Developmental validation of the quantifiler real-time PCR kits for the quantification of human nuclear DNA samples. J Forensic Sci 50: 809-825, 2005

40. Shablii VA, Kuchma MD, Kyryk VM, Svitina HM, Shablii YM, Lukash LL and Lobintseva GS: Mesenchymal and trophoblast immunophenotype of multipotent stromal cells from human placenta. Biopolym Cell 30: 118-121, 2014. 
41. Shablii V, Kuchma M, Kyryk V, Onishchenko G, Areshkov P, Skrypnyk N, Lukash L and Lobyntseva G: Characteristics of placental multipotent mesenchymal stromal stem cells. Cell Transplant tissue Eng 7: 53-59, 2012.

42. Dominici M, Le Blanc K, Mueller I, Slaper-Cortenbach I, Marini F, Krause D, Deans R, Keating A, Prockop Dj and Horwitz E: Minimal criteria for defining multipotent mesenchymal stromal cells. The international society for cellular therapy position statement. Cytotherapy 8: 315-317, 2006.

43. Ulrich C, Rolauffs B, Abele H, Bonin M, Nieselt K, Hart ML and Aicher WK: Low osteogenic differentiation potential of placenta-derived mesenchymal stromal cells correlates with low expression of the transcription factors Runx2 and Twist2. Stem Cells Dev 22: 2859-2872, 2013.

44. Heo JS, Choi Y, Kim HS and Kim HO: Comparison of molecular profiles of human mesenchymal stem cells derived from bone marrow, umbilical cord blood, placenta and adipose tissue. Int J Mol Med 37: 115-125, 2016.

45. Garzón I, Alfonso-Rodríguez CA, Martínez-Gómez C, Carriel V, Martin-Piedra MA, Fernández-Valadés R, Sánchez-Quevedo MC and Alaminos M: Expression of epithelial markers by human umbilical cord stem cells. A topographical analysis. Placenta 35: 994-1000, 2014.

46. Hue I, Evain-Brion D, Fournier T and Degrelle SA: Primary bovine extra-embryonic cultured cells: A new resource for the study of in vivo peri-implanting phenotypes and mesoderm formation. PLoS One 10: e0127330, 2015.

47. Qian H, Le Blanc K and Sigvardsson M: Primary mesenchymal stem and progenitor cells from bone marrow lack expression of CD44 protein. J Biol Chem 287: 25795-25807, 2012.

48. Baustian C, Hanley S and Ceredig R: Isolation, selection and culture methods to enhance clonogenicity of mouse bone marrow derived mesenchymal stromal cell precursors. Stem Cell Res Ther 6: 151, 2015.

49. Bernardo AS, Faial T, Gardner L, Niakan KK, Ortmann D, Senner CE, Callery EM, Trotter MW, Hemberger M, Smith JC, et al: BRACHYURY and CDX2 mediate BMP-induced differentiation of human and mouse pluripotent stem cells into embryonic and extra embryonic lineages. Cell Stem Cell 9: $144-155,2011$.

50. Mendjan S, Mascetti VL, Ortmann D, Ortiz M, Karjosukarso DW, $\mathrm{Ng}$ Y, Moreau T and Pedersen RA: NANOG and CDX2 pattern distinct subtypes of human mesoderm during exit from pluripotency. Cell Stem Cell 15: 310-1325, 2014

51. Davenport C, Diekmann U, Budde I, Detering N and Naujok O The anterior-posterior patterning of definitive endoderm generated from human embryonic stem cells depends on the differential signaling of retinoic acid, Wnt,- and BMP-signaling. Stem Cells: Jun 14, 2016 (Epub ahead of print).

52. Teo AK, Arnold SJ, Trotter MW, Brown S, Ang LT, Chng Z, Robertson EJ, Dunn NR and Vallier L: Pluripotency factors regulate definitive endoderm specification through eomesodermin. Genes Dev 25: 238-250, 2011.

53. van den Ameele J, Tiberi L, Bondue A, Paulissen C, Herpoel A, Iacovino M, Kyba M, Blanpain $\mathrm{C}$ and Vanderhaeghen $\mathrm{P}$ : Eomesodermin induces Mesp1 expression and cardiac differentiation from embryonic stem cells in the absence of Activin. EMBO Rep 13: 355-362, 2012.

54. Knox JJ, Cosma GL, Betts MR and McLane LM: Characterization of T-bet and Eomes in peripheral human immune cells. Front Immunol 5: 217, 2014.

55. Simonetta F, Pradier A and Roosnek E: T-bet and eomesodermin in NK cell development, maturation, and function. Front Immunol 7: 241, 2016.

56. Shi $\mathrm{G}$ and Jin Y: Role of Oct4 in maintaining and regaining stem cell pluripotency. Stem Cell Res Ther 1: 39, 2010.

57. Jerabek S, Merino F, Schöler HR and Cojocaru V: OCT4: Dynamic DNA binding pioneers stem cell pluripotency. Biochim Biophys Acta 1839: 138-154, 2014

58. Parenti A, Halbisen MA, Wang K, Latham K and Ralston A: OSKM induce extraembryonic endoderm stem cells in paralle to induced pluripotent stem cells. Stem Cell Reports 6: 447-455, 2016.

59. Noisa P, Ramasamy TS, Lamont FR, Yu JS, Sheldon MJ, Russell A, Jin X and Cui W: Identification and characterisation of the early differentiating cells in neural differentiation of human embryonic stem cells. PLoS One 7: e37129, 2012.

60. Knott JG and Paul S: Transcriptional regulators of the trophoblast lineage in mammals with hemochorial placentation. Reproduction 148: R121-R136, 2014.
61. DeVeale B, Brokhman I, Mohseni P, Babak T, Yoon C, Lin A, Onishi K, Tomilin A, Pevny L, Zandstra PW, et al: Oct4 is required $\sim$ E7.5 for proliferation in the primitive streak. PLoS Genet 9: e1003957, 2013.

62. Nazarov I, Lee JW, Soupene E, Etemad S, Knapik D, Green W, Bashkirova E, Fang X, Matthay MA, Kuypers FA and Serikov VB: Multipotent stromal stem cells from human placenta demonstrate high therapeutic potential. Stem Cells Transl Med 1: 359-372, 2012.

63. Janatpour MJ, McMaster MT, Genbacev O, Zhou Y, Dong J, Cross JC, Israel MA and Fisher SJ: Id-2 regulates critical aspects of human cytotrophoblast differentiation, invasion and migration. Development 127: 549-558, 2000.

64. Gultice AD, Selesniemi KL and Brown TL: Hypoxia inhibits differentiation of lineage-specific Rcho-1 trophoblast giant cells Biol Reprod 74: 1041-1050, 2006

65. Jen Y, Manova K and Benezra R: Each member of the Id gene family exhibits a unique expression pattern in mouse gastrulation and neurogenesis. Dev Dyn 208: 92-106, 1997.

66. Selesniemi K, Albers RE and Brown TL: Id2 mediates differentiation of labyrinthine placental progenitor cell line, SM10. Stem Cells Dev 25: 959-974, 2016.

67. Iyer S, Viernes DR, Chisholm JD, Margulies BS and Kerr WG: SHIP1 regulates MSC numbers and their osteolineage commitment by limiting induction of the PI3K/Akt/beta-catenin/Id2 axis. Stem Cells Dev 23: 2336-2351, 2014.

68. Simmons DG and Cross JC: Determinants of trophoblast lineage and cell subtype specification in the mouse placenta. Dev Biol 284: 12-24, 2005

69. Rai A and Cross JC: Development of the hemochorial maternal vascular spaces in the placenta through endothelial and vasculogenic mimicry. Dev Biol 387: 131-141, 2014.

70. Gasperowicz M, Surmann-Schmitt C, Hamada Y, Otto F and Cross JC: The transcriptional co-repressor TLE3 regulates development of trophoblast giant cells lining maternal blood spaces in the mouse placenta. Dev Biol 382: 1-14, 2013

71. Tunster SJ, McNamara GI, Creeth HD and John RM: Increased dosage of the imprinted Ascl2 gene restrains two key endocrine lineages of the mouse Placenta. Dev Biol 418: 55-65, 2016.

72. Deussing J, Kouadio M, Rehman S, Werber I, Schwinde A and Peters C: Identification and characterization of a dense cluster of placenta-specific cysteine peptidase genes and related genes on mouse chromosome 13. Genomics 79: 225-240, 2002.

73. Simmons DG, Fortier AL and Cross JC: Diverse subtypes and developmental origins of trophoblast giant cells in the mouse placenta. Dev Biol 304: 567-578, 2007.

74. Yabe S, Alexenko AP, Amita M, Yang Y, Schust DJ, Sadovsky Y, Ezashi T and Roberts RM: Comparison of syncytiotrophoblast generated from human embryonic stem cells and from term placentas. Proc Natl Acad Sci USA 113: E2598-E25607, 2016.

75. Pianta S, Bonassi Signoroni P, Muradore I, Rodrigues MF, Rossi D, Silini A and Parolini O: Amniotic membrane mesenchymal cells-derived factors skew T cell polarization toward treg and downregulate Th1 and Th17 cells subsets. Stem Cell Rev 11: 394-407, 2015

76. Weiss ML, Anderson C, Medicetty S, Seshareddy KB, Weiss RJ VanderWerff I, Troyer D and McIntosh KR: Immune properties of human umbilical cord Wharton's jelly-derived cells. Stem Cells 26: 2865-2874, 2008 .

77. Wang M, Yang Y, Yang D, Luo F, Liang W, Guo S and Xu J: The immunomodulatory activity of human umbilical cord blood-derived mesenchymal stem cells in vitro. Immunology 126 : 220-232, 2009

78. Parolini O, Alviano F, Bergwerf I, Boraschi D, De Bari C, De Waele P, Dominici M, Evangelista M, Falk W, Hennerbichler S, et al: Toward cell therapy using placenta-derived cells: Disease mechanisms, cell biology, preclinical studies, and regulatory aspects at the round table. Stem Cells Dev 19: $143-154,2010$

79. Talwadekar MD, Kale VP and Limaye LS: Placenta-derived mesenchymal stem cells possess better immunoregulatory properties compared to their cord-derived counterparts-a paired sample study. Sci Rep 5: 15784, 2015.

80. De Girolamo L, Lucarelli E, Alessandri G, Avanzini MA, Bernardo ME, Biagi E, Brini AT, D'Amico G, Fagioli F, Ferrero I, et al: Mesenchymal stem/stromal cells: A new 'cells as drugs' paradigm. Efficacy and critical aspects in cell therapy. Curr Pharm Des 19: 2459-2473, 2013.

81. Mattar P and Bieback K: Comparing the immunomodulatory properties of bone marrow, adipose tissue, and birth-associated tissue mesenchymal stromal cells. Front Immunol 6: 560, 2015. 
82. Zhu W, Xu W, Jiang R, Qian H, Chen M, Hu J, Cao W, Han C and Chen Y: Mesenchymal stem cells derived from bone marrow favor tumor cell growth in vivo. Exp Mol Pathol 80: 267-274, 2006.

83. Wang S, Qu X and Zhao RC: Clinical applications of mesenchymal stem cells. J Hematol Oncol 5: 19, 2012.

84. Wu CG, Zhang JC, Xie CQ, Parolini O, Silini A, Huang YZ, Lian B, Zhang M, Huang YC and Deng L: In vivo tracking of human placenta derived mesenchymal stem cells in nude mice via ${ }^{14} \mathrm{C}-\mathrm{TdR}$ labeling. BMC Biotechnol 15: 55, 2015.

85. Cargnoni A, Gibelli L, Tosini A, Signoroni PB, Nassuato C, Arienti D, Lombardi G, Albertini A, Wengler GS and Parolini O: Transplantation of allogeneic and xenogeneic placenta-derived cells reduces bleomycin-induced lung fibrosis. Cell Transplant 18: 405-422, 2009

86. Cao H, Yang J, Yu J, Pan Q, Li J, Zhou P, Li Y, Pan X, Li J, Wang Y and $\mathrm{Li} \mathrm{L}$ : Therapeutic potential of transplanted placental mesenchymal stem cells in treating Chinese miniature pigs with acute liver failure. BMC Med 10: 56, 2012.

87. Von Bahr L, Batsis I, Moll G, Hägg M, Szakos A, Sundberg B, Uzunel M, Ringden $\mathrm{O}$ and Le Blanc K: Analysis of tissues following mesenchymal stromal cell therapy in humans indicates limited long-term engraftment and no ectopic tissue formation. Stem Cells 30: 1575-1578, 2012.
88. Silini AR, Cargnoni A, Magatti M, Pianta S and Parolini O: The long path of human placenta, and its derivatives, in regenerative medicine. Front Bioeng Biotechnol 3: 162, 2015.

89. Lee RH, Pulin AA, Seo MJ, Kota DJ, Ylostalo J, Larson BL, Semprun-Prieto L, Delafontaine P and Prockop DJ: Intravenous hMSCs improve myocardial infarction in mice because cells embolized in lung are activated to secrete the anti-inflammatory protein TSG-6. Cell Stem Cell 5: 54-63, 2009.

90. Passipieri JA, Kasai-Brunswick TH, Suhett G, Martins AB, Brasil GV, Campos DB, Rocha NN, Ramos IP, Mello DB, Rodrigues DC, et al: Improvement of cardiac function by placenta-derived mesenchymal stem cells does not require permanent engraftment and is independent of the insulin signaling pathway. Stem Cell Res Ther 5: 102, 2014.

91. Meier RP, Müller YD, Morel P, Gonelle-Gispert C and Bühler LH: Transplantation of mesenchymal stem cells for the treatment of liver diseases, is there enough evidence? Stem Cell Res 11: 1348-1364, 2013. 